\title{
Economic Efficiency Assessment \\ for Technological Solutions in the Oil and Gas Industry Using Monte Carlo Method
}

\author{
Anastasia E. Kasimova and Alexander K. Moskalev* \\ Siberian Federal University \\ 79 Svobodny, Krasnoyarsk, 660041, Russia
}

Received 22.10.2015, received in revised form 18.01.2016, accepted 27.02.2016

The article presents the results of a search for an adequate method of assessing economic efficiency of an innovative oil deposit development project offered for investment. The tools currently used for project assessment are seen as insufficient, and the results they provide are not informative enough for investment decision-making. The currently used methods do not consider the impact made by external and internal risk factors on the ultimate efficiency value; therefore, the investment efficiency assessment problem still remains urgent. One of the ways to solve the problem is to apply Monte Carlo simulation method for the investment efficiency analysis. The research analyses a real project for reservoir pressure maintenance system pumping units used in oil deposit development. In order to prove the accuracy of the obtained results and the efficiency of the assessment tool, the data were compared to the ones calculated with a method where the main efficiency indicator is net present value. The research results lead us to conclusion on the appropriateness of using such additional investment project selection tools as Monte Carlo method, along with the traditional ones.

Keywords: investment, economic efficiency, net present value, Monte Carlo method.

DOI: 10.17516/1997-1370-2016-9-4-815-823.

Research area: culture studies, economics.

\section{Introduction}

For any oil and gas extracting company the main course of new technical solution development is the work on the economical deposit development problem. Today there is a great number of works written by both Russian and foreign authors devoted to the economic efficiency assessment of innovative projects. The main indicator of an innovative technology project's attractiveness is economic efficiency of the investment it requires. Today the most popular approach is the income approach to economic assessment of projects, where the main attractiveness criteria are such indicators as net present value, or NPV, internal rate of return (IRR), return of investment (ROI) etc.

Even though the issue has been well negotiated, there is a number of key problems concerning the economic assessment result validity that still remain understudied. During the innovative technology and solution implementation project analysis the final

(C) Siberian Federal University. All rights reserved

* Corresponding author E-mail address: kafedra_efit@mail.ru 
efficiency indicators are under influence of a number of factors that may be insufficiently assessed at the primary stage, but that may change later in the project implementation process. For this reason for economic efficiency calculation it is right to consider the expected mean values of the indicators influencing the final decision, and omit possible deviations from the initial values.

Due to the input parameters' fluctuations, manual calculation of economic efficiency indicators is a long and tedious process; moreover, processing large quantities of data with the analytical method is impractical without special software, so the task of economic efficiency assessment of innovative oil deposit development projects is not completely fulfilled.

To obtain risk-informed innovative project economic assessment, it is hereby suggested to use Monte Carlo method. The present article demonstrates the opportunities of Monte Carlo computer simulation for economic efficiency assessment based on a real project on pumping station drive replacement at oil deposit development.

\section{Project summary}

The deposits developed in the territories of Western and Eastern Siberia contain, as a rule, some hard-to-recover reserves, and are located in remote regions with weak or absent infrastructure. For this reason the most topical task to be economically and rationally fulfilled for such deposits' development is the task of stable electric power supplies and energy efficiency.

The greatest part of power consumption in oil and gas industry falls on reservoir pressure maintenance system (RPM). The main object that ensures collection and pumping of fresh water, formation water and waste water into the formation is a modular cluster pump station
(MCPS). The volume of electric power consumed by RPM system equipment constitutes $30-40 \%$ of total energy consumption.

Traditionally modular cluster pump stations are equipped with asynchronous motors. The in-rush current rate that occurs at the start of powerful asynchronous motors exceeds the rated current by 4-7 times, causing undertension in the whole power supply system. There are expensive soft motor starter devices used today, but they do not solve the problem as they only decrease the in-rush current rate to 3-3.5 of the rated current.

One of the conceptual options of the oil deposit power supply system stabilization is the use of gas-turbine driven pump units on modular cluster stations for pumping water into the formation. The use of gas-turbine driven pump units will exclude energy system loads that destabilize its work. It is suggested to use associated petroleum gas (APG) extracted during oil extraction to supply the system.

It was decided to implement the solution at Oskobinsky license block of VostSibNefteGas OJSC for the following reasons:

- the site is remote from power supply unit;

- planned gas extraction volume is 80 billion $\mathrm{m}^{3}$;

- there are no alternative APG use options;

- site objects are concentrated: there is no need to build any additional dielectric cabling systems.

From the technological point of view, implementation of a gas turbine-driven MCPS in the selected block is practical, but the cost of such unit is significantly higher than that of an electrically driven MCPS. Moreover, gas turbine maintenance requires additional personnel recruitment which increases operating costs. Therefore, it is necessary to perform economic efficiency analysis of the suggested project. 


\section{Economic efficiency analysis with the use of traditional indicators}

Implementation of the energy efficiency solutions described above at Oskobinsky LB requires additional investments due to increase of the MCPS cost as a result of replacement of electrically driven pumping units with gas turbine-driven ones. In its turn, the power consumption decrease leads to decreasing the costs of electric stations and ETL construction, as well as maintenance costs. Moreover, it decreases the costs of the RPM system pump unit maintenance due to lower tariffs for gas turbine-driven objects' maintenance. Therefore, there occurs a cash flow that may be used to assess the plan efficiency manifested in the decrease (increase) of the gas turbine operation costs.

The use of gas turbine-driven pump units at the Oskobinsky LB MCPS requires the following modifications in the power supply system:

- decrease the number of reciprocating gas and diesel motors from five to three;

- replace the packaged transformer substation 2KTPB 2x4000 with KTP-63.

To enhance the deposit development oil recovery efficiency, it is planned to install a heat recovery unit, i.e. install hot exhaust heat boilers on the gas-turbine station to produce hot water for industrial and household needs.

The changes in the costs of objects to be removed or added, caused by the use of the MCPS with the gas turbine-driven pump units (besides the change in the cost of the MCPS itself) are shown in Table 1.

To calculate the changes in MCPS construction costs, the suggested contractors were contacted for the estimated costs of purchase, MCPS construction and assembly works, as well as some additional information (presented in Table 2).

To select the manufacturer and calculate the cost of a MCPS with gas turbine-driven pump units, a cash flow was formed as a difference of purchase and maintenance costs. As a result, German brand Sulzer was chosen as the most economically efficient manufacturer.

The price of a basic MCPS with electrically driven pumping unit used during the analysis is the estimated cost provided by Block and Unit Devices Plant OJSC, as the second manufacturer, Gidromashservice OJSC, did not provide full information that was inquired.

Oskobinsky LB development project efficiency is evaluated by means of comparative analysis of the main economic efficiency indicators, as well as cash flows under the standard arrangement scheme and the arrangement scheme using energy saving technologies in the RPM system. The expected cost reduction is presented in Table 3, year-wise.

As we can see from Table 3, energy saving technology implementation makes a positive impact on economic efficiency: discounted costs reduction for 10 years reaches 111 million roubles.

Table 1. Changes in capital expenditure

\begin{tabular}{|l|c|c|c|}
\hline & Quantity, units & Unit cost, RUR/unit & $\begin{array}{c}\text { Total increase/decrease } \\
\text { of costs, in thousands RUR }\end{array}$ \\
\hline RGDM & -2 & 91598 & -183196 \\
\hline 2KTPB 2x4000 & -1 & 5607 & -5607 \\
\hline KTP-63 & +1 & 234 & +234 \\
\hline Water boilers & +5 & 11000 & +55000 \\
\hline
\end{tabular}


Table 2. Comparative characteristics of MCPS with variously driven pump units

\begin{tabular}{|c|c|c|c|c|c|c|}
\hline & Manufacturer & $\begin{array}{c}\text { MCPS } \\
\text { cost (VAT } \\
\text { excluded), in } \\
\text { thousands RUR }\end{array}$ & $\begin{array}{c}\text { MCPS current } \\
\text { maintenance } \\
\text { cost, } \\
\text { in thousands } \\
\text { RUR/year }\end{array}$ & $\begin{array}{c}\text { MCPS overhaul } \\
\text { cost, } \\
\text { in thousands } \\
\text { RUR }\end{array}$ & $\begin{array}{l}\text { Warranty } \\
\text { period, } \\
\text { months }\end{array}$ & $\begin{array}{c}\text { Overhaul } \\
\text { life, } \\
\text { months }\end{array}$ \\
\hline \multirow{2}{*}{ 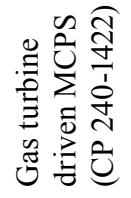 } & Sulzer & 315750 & 385 & 924 & 60 & 60 \\
\hline & $\begin{array}{l}\text { Kirov-Energomash } \\
\text { Plant CJSC }\end{array}$ & 378980 & 378 & 907 & 36 & 60 \\
\hline \multirow{2}{*}{ 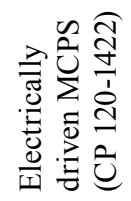 } & $\begin{array}{l}\text { Gidromashservice } \\
\text { OJSC }\end{array}$ & 275500 & no data & no data & no data & 36 \\
\hline & $\begin{array}{l}\text { Block and Unit } \\
\text { Devices Plant OJSC }\end{array}$ & 270705 & 766 & 1230 & 24 & 36 \\
\hline
\end{tabular}

\section{Economic efficiency analysis with the use}

\section{of Monte Carlo computer simulation}

Despite the practicality of implementation of a MCPS with a gas turbine driven motor, it is still necessary to perform an additional project efficiency analysis with regard to uncertainty factors, as the lack of attention to the factors that may influence the financial rate of the project return may lead to wrong investment decisions and significant losses.

One of the methods of calculating uncertainty factors influence on the final efficiency indicator is Monte Carlo computer simulation method. In the context of economic efficiency, the method is based on multiple modelling of various factor combinations that may influence the final project efficiency rate. Thus, the result of this method application is probability distribution of the final efficiency rate values.

To perform the pump unit motor replacement efficiency calculation, the assessment shall be done on three main parameters:

- equipment cost (in Euros);

- Euro vs. Rouble exchange rate;
- changes of operating costs.

These parameters are modelled as random values having their probability distribution.

For Euro exchange rate simulation, triangular distribution is used. Triangular distribution has three parameters: minimum, maximum and the likemost.

As the likemost value, the current Euro exchange rate of the RF CB was selected. The value is 70.40 RUR. Minimum value of the indicator is 70.00 RUR. Maximum value was chosen at the rate of 75.00 RUR. Euro exchange rate values distribution is illustrated in Fig. 1.

Triangular distribution was also selected for the initial equipment cost simulation. However, the likemost and the minimum prices values were set at the value suggested by Sulzer representative for the current moment. The maximum value was the cost increased by $11 \%$ against the initial price. Equipment cost distribution is illustrated in Fig. 2.

Operating costs distribution is simulated through normal distribution with the expected value of 16057 thousand RUR/year and deviation of $1 \%$. Graphically operating costs value distribution is illustrated in Fig. 3. 


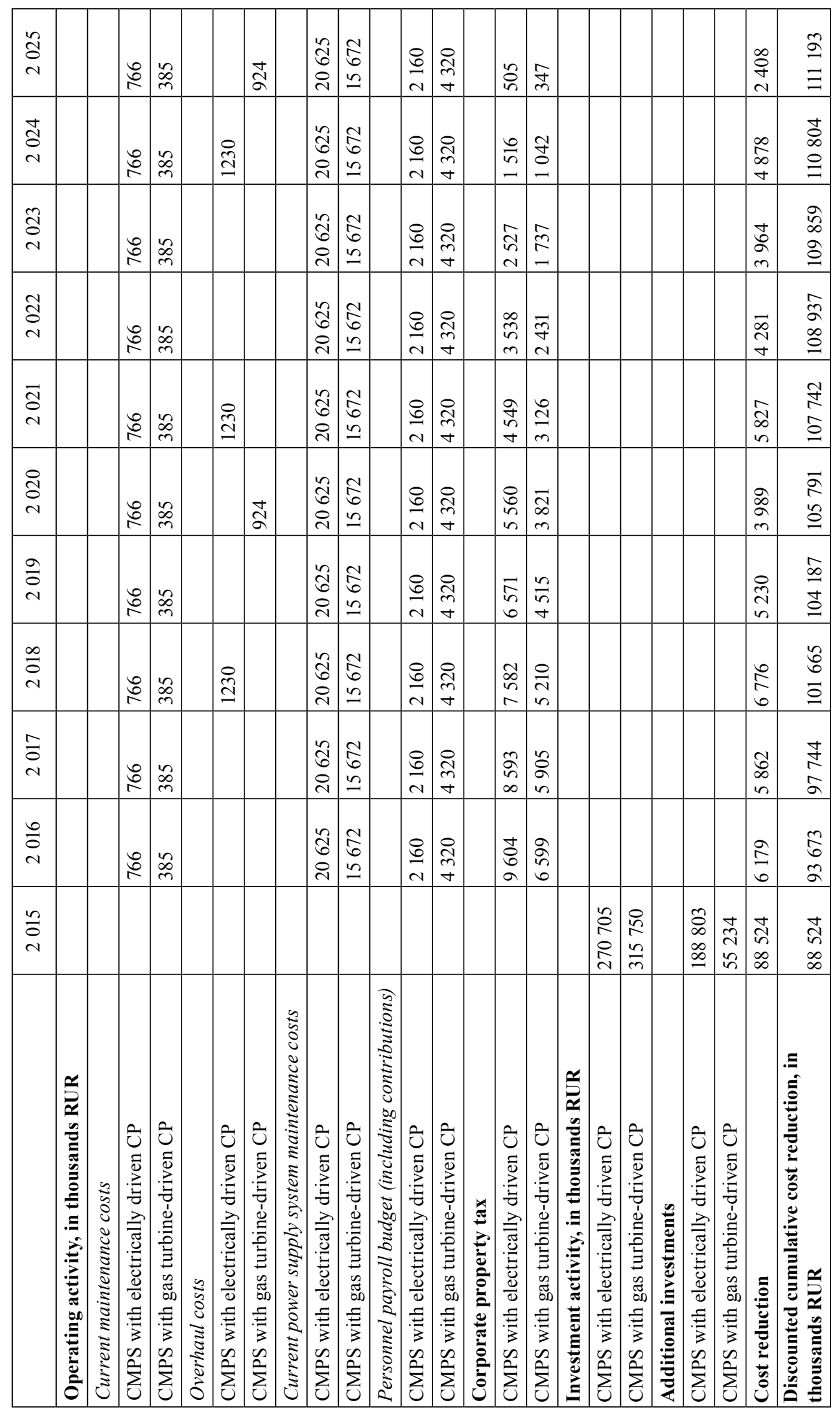




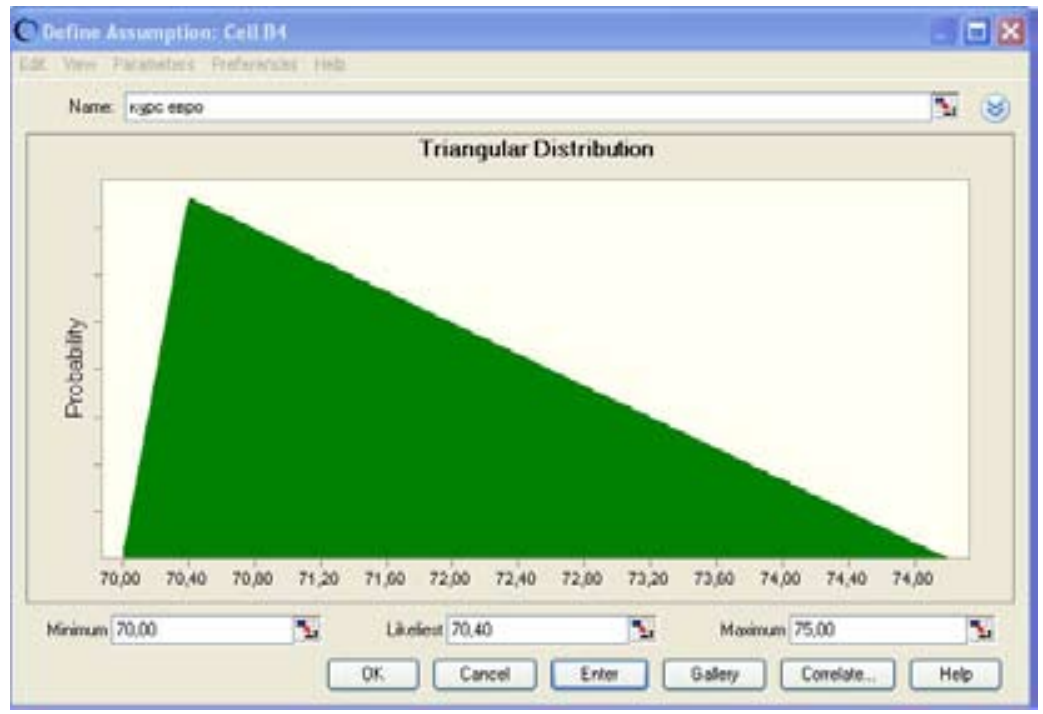

Fig. 1. Triangular distribution of Euro exchange rate

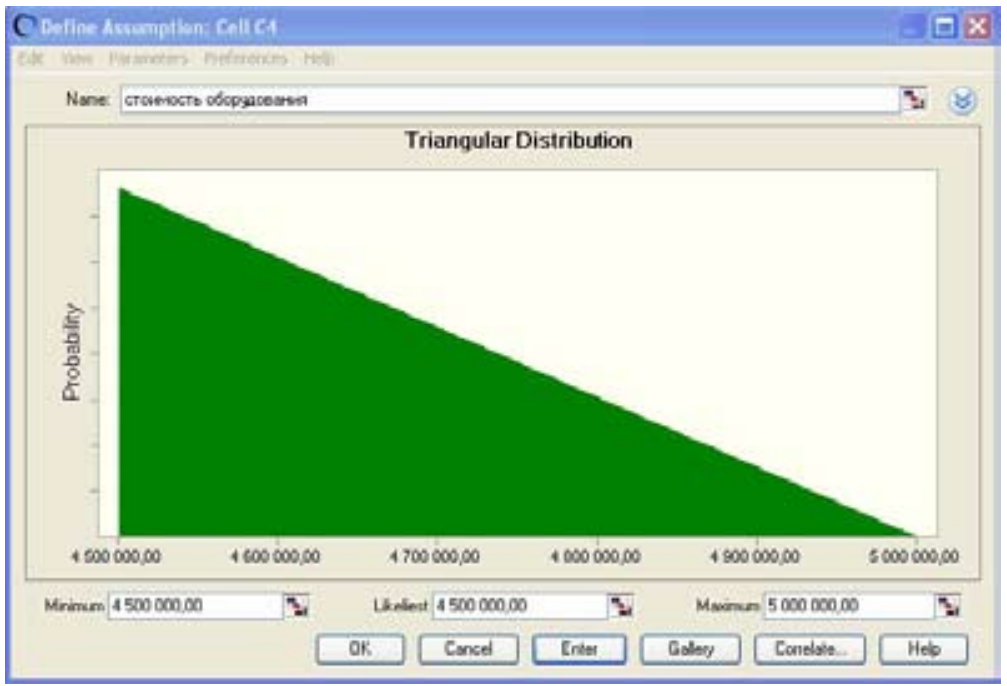

Fig. 2. Triangular distribution of equipment cost

In the process of Monte Carlo analysis 100000 repetitions were made. At each repetition the program generated new values for random variables from the set distributions and calculated the project NPV. The analysis result is presented as a histogram in Fig. 4 and summarized in Table 4.

As we can see from the Table, the mean value of the project NPV constitutes 101104 thousand RUR, which is a little lower than the standard model NPV (111 193 thousand RUR). Analysis performed with Monte Carlo simulation leads us to the statement that the probability of positive economic efficiency of the present project is $100 \%$. However, the forecasted NPV values obtained with a standard model are not valid enough. As we can see from Fig. 4, the probability of some funds saving with a hydraulically driven MCPS implementation calculated with the NPV 


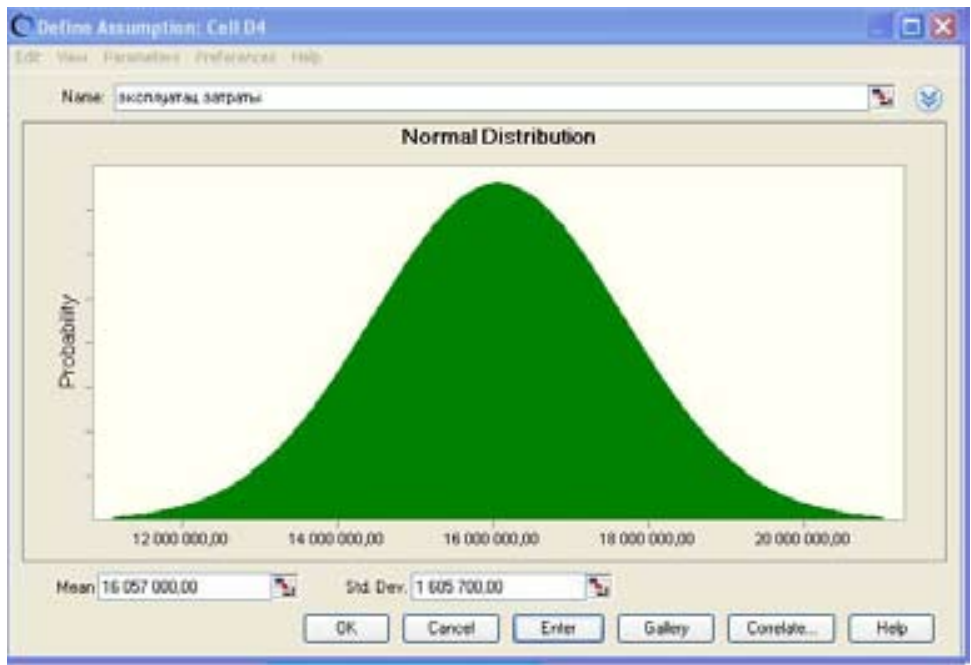

Fig. 3. Normal distribution of operating costs

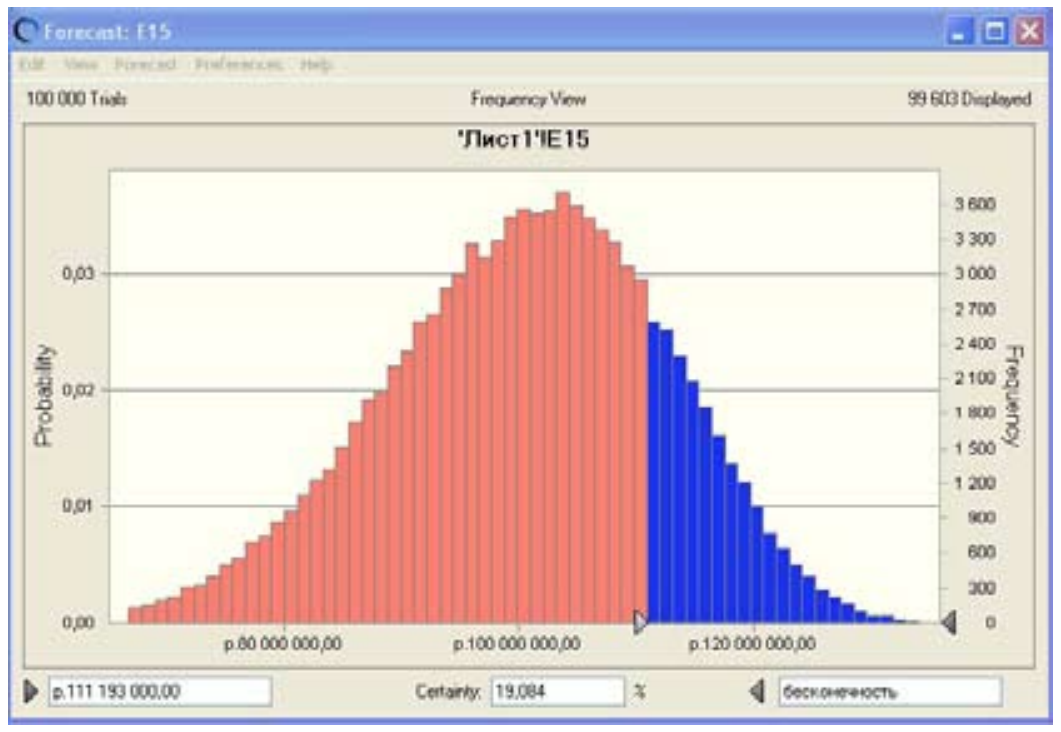

Fig. 4. Probability distribution of NPV values

indicator is only $19 \%$. Therefore, only in one fifths of all cases, under a certain combination of factors the company may achieve the practicality calculated with the standard model.

The results lead us to the conclusion on sufficiency of applying computer simulation method to assess economic efficiency of innovative projects due to the opportunity of considering the simultaneous impact of risk factors on the final value and achieving more accurate results for consistent innovation decision-making.

\section{Software used}

\section{for Monte Carlo simulation}

All calculations described in the article were performed with Cristal Ball software by Decisioneering, which is a Microsoft Excel extension. 
Table 4. General Monte Carlo analysis results

\begin{tabular}{|c|c|c|}
\hline Mean value & Maximum value & Minimum value \\
\hline 101104029.8 RUR & 140643523.58 RUR & 49774461.40 RUR \\
\hline
\end{tabular}

\section{References}

Baiandina, V.A., Voronin, D.M. (2015). To the question of efficiency assessment of strategic investment projects at oil and gas extraction enterprises, In Bulletin of Perm State University, 1(24), 111-123.

Boykova, G.V. (2010). Monte Carlo method for risk assessment of investment projects, In Studies of Russian State Social University, 8, 253-257.

Lukashov, A.V. (2007). Monte Carlo method for financial analysts: brief guide, In Management of corporate finance, 01 (19), 22-39.

Nikonova, I.A., Kolesnikov, M.A. (2013). Development of methods for investment project analysis and assessment, In Bulletin of the University of Finance, 6, 89-97.

Rabinovich, L.M., Fadeeva, E.P. (2014). Scientific management for investment process, In Actual problems of Economics and Law, 4, 175-182. 


\title{
Оценка экономической эффективности
}

\section{технологических решений}

в нефтегазовом комплексе методом Монте-Карло

\author{
А.Э. Касимова, А.К. Москалев \\ Сибирский федеральный университет \\ Россия, 660041, Красноярск, пр. Свободный, 79
}

\begin{abstract}
Представлены результаты исследования, направленного на поиск адекватной оиенки экономической эффективности инновационного проекта, предлагаемого к инвестированию, при разработке нефтяного месторождения. Современный инструментарий, используемый при оиенке проектов, представляется недостаточно эффективным, а его результать недостаточно информативными для принятия инвестиционных решений. Используемые методы не позволяют учесть влияние внешних и внутренних факторов риска на показания итоговой эффективности, в связи с чем проблема получения достоверной оценки эффективности вложений является актуальной. Одним из способов решения данной проблемы является применение для анализа эффективности инвестиций метода компьютерного моделирования Монте-Карло. В статье анализируется реальный проект по замене насосных установок системы поддержания пластового давления при разработке нефтяных месторождений. Для доказательства эффективности инструмента оценки и достоверности получаемых результатов был проведен сравнительный анализ с данными, полученными методом, при котором основным показателем эффективности является чистый дисконтированный доход. Результаты исследования позволяют сделать вывод о целесообразности применения наряду с традиционными методами оценки дополнительных инструментов для отбора инвестиционных проектов, одним из которых может являться метод Монте-Карло.
\end{abstract}

Ключевые слова: инвестиции, экономическая эффективность, чистый дисконтированный доход, метод Монте-Карло.

Научная специальность: 24.00.00 - культурология, 08.00.00 - экономические науки. 